\title{
工科系大学の教養教育における導入プログラムの効果 (3)
}

\author{
課題タイプによる効果の違い \\ 黒沢学 \\ (東京電機大学未来科学部) \\ キーワード : 初年次教育・高等教育・転移
}

Effects of the first year experience program in the faculty of engineering (3)

KUROSAWA Manabu

(School of Science and Technology for Future Life, Tokyo Denki Univ.)

Key Words: first-year experience, higher education, transfer

\section{目 的}

18 歳人口の減少と大学教育のユニバーサル化をうけ，大学 入学者の「学力」が多様化する中で, 大学入学者への初年次 教育が重要であるとの認識は広く共有されるようになってき た。しかし，我が国においてどのような教育プログラムが必 要なのか, それはどのようなメカニズムで・どの程度望まし い効果を持つのか，などについての実証的な研究はまだ十分 に行われているわけではない.

筆者はこの問題に関して, 主に自分が勤務する大学におけ る初年次教育の内容と, 受講者/非受講者のその後の成績を もとにした分析を継続的に行ってきた(黒沢, 2010a, 2010b). その結果を要約すると,「平均的にいえば，望ましい効果は口 バストであるが，効果量自体は大きくない」というものにな る.

ではなぜそのような結果になるのだろうか. ひとつ考えら れるのは, 初年次教育は大学教育の多くの場面で用いられる スキルを扱うことが多いので，そこでしばしば「レポートの 書き方」が扱われるが，その後の大学教育では，それが必要 になる科目とそうでない科目があり，平均寸るとその効果が 小さく見積もられるのでないか，ということである。もしそ うであれば，レポートを書かせないような，知識を主に扱う 科目では初年次教育の望ましい効果が低くなっていることが 予測される，そのことを確かめるために，筆者の行った科目 のうち, 文章作成よりも知識を確認する科目で, 初年次教育 の転移の効果を調べる。

\section{方 法}

【調査対象者】東京電機大学神田/千住キャンパスの学生の うち，2012，2013 年度に「認知心理学」を受講した学生 134 名. 1 年生は履修できないので， $2 ， 3 ， 4$ 年生がいるが， 4 年 生はわずかであるので 3 年生と込みにして分析する.

【課題】当該科目は人間科学(一般教養)科目にあたり, どの 学科の学生も履修可能である. 評価は学期中の小テスト(教科 書などを見ながら穴埋めに答える，15 点 $\times 4$ 回）と平常点・最 終の試験 (論述) からなる. 今回はそのうちの小テストの成績 を従属変数として用いる.

\section{結 果}

【初年次教育の効果】まず，全体を込みにして初年次教育の 履修登録の有無によって 2 群に分け, 小テストの合計の成績 の平均差を検定した. 寸ると, 履修者の平均は非履修者より も高い傾向が見られた $(\mathrm{t}(132)=1.71, \mathrm{p}<.1)$. 表を参照.

【学年の効果】次いで, 履修時の学年を考慮して, 履修の有 無 $(2) \times$ 学年 $(2)$ を独立変数とし, 小テスト成績を従属変数と する 2 要因の分散分析を行った. すると, 学年の主効果がみ
られ $(\mathrm{F}(1,130)=10.93, \mathrm{p}<.001)$ ，また交互作用は有意な傾 向であった $(\mathrm{F}(1,130)=3.05, \mathrm{p}<.1)$. 図を参照.

\section{表：初年次教育履修が小テスト成績に及ぼす効果}

\begin{tabular}{|c|c|c|c|}
\hline 条件 & $\mathrm{n}$ & mean & $\mathrm{sd}$ \\
\hline 不履修 & 54 & 36.2 & 20.5 \\
\hline 履修 & 80 & 41.8 & 17.0 \\
\hline
\end{tabular}

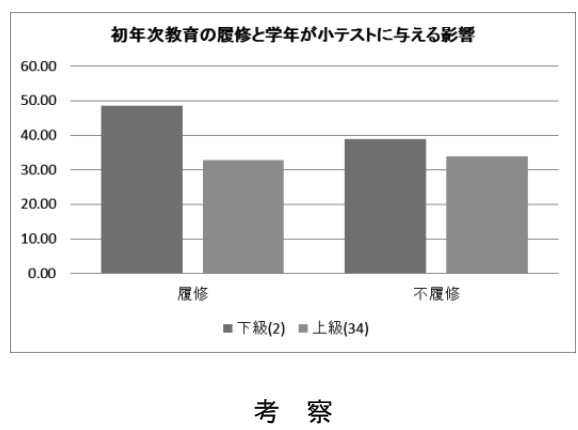

「ロバストに，しかし小さい効果」という結果は，今回も 同様に観察された. 全員を込みにした場合, 効果量は小さい が履修者は小テスト成績もよい傾向が見られた.これを、レ ポート作成と比較して効果が小さくなったと解釈することは 現段階ではできない，今後の検討が必要である。

その解釈をする際に履修年次との交互作用のパタンが参考 になると思われる. 全般的に若い年次で成績がよく, またそ こで大きく履修の有無の差があるということは, この科目が 履修できるようになってすぐに関心のある科目を履修した， そしてそのような条件で特に初年次教育を履修したものが成 績がよい，と考えることができる. とはいえ，これについて はまだ継続的なデータの収集が必要であると考えられる.

\section{引用文献}

黒沢学 2010a 東京電機大学神田キャンパスにおける初年次教 育リメディアル教育研究, 5(2).

黒沢学 2010b 工科系大学の教養教育における導入プログラ 么の効果 (2) 日本心理学会第 74 回大会発表論文集. 